\title{
Life cycle greenhouse gas benefits or burdens of residual biomass from landscape management
}

\author{
Swinda F. Pfau ${ }^{a}{ }^{*}$, Steef V. Hanssen ${ }^{b}$, Menno W. Straatsmac, K. Remon Koopman ${ }^{\text {b,d }}$, Rob S.E.W. \\ Leuven ${ }^{d}$, Mark A.J. Huijbregts ${ }^{b}$ \\ a Institute for Science in Society, Radboud University, P.O. Box 9010, Nijmegen 6500 GL, The \\ Netherlands \\ ${ }^{b}$ Department of Environmental Science, Institute for Water and Wetland Research, Radboud \\ University, P.O. Box 9010, 6500 GL Nijmegen, The Netherlands \\ 'Department of Physical Geography, Utrecht University, P.O. Box 80115, 3508 TC Utrecht, The \\ Netherlands \\ ${ }^{d}$ Department of Animal Ecology and Physiology, Institute for Water and Wetland Research, Radboud \\ University, P.O. Box 9010, 6500 GL Nijmegen, The Netherlands
}

\section{"Corresponding author. E-mail address: swinda.pfau@ru.nl}

\begin{abstract}
The use of residual biomass for the production of bioenergy and biomaterials is often suggested as a strategy to avoid negative effects associated with dedicated biomass production. One potential source is biomass from landscape management. The goal of this study was to find the lowest net greenhouse gas (GHG) emissions of various applications of residual biomass from landscape management. GHG balances of thirteen residual biomass applications were calculated and compared to their respective conventional counterfactuals. As a case study, the potential contribution to climate change mitigation through the use of residual biomass available from vegetation management in floodplains of the Dutch Rhine delta were quantified. The greatest GHG benefits are achieved when using woody biomass to produce heat $(-132 \mathrm{~kg} \mathrm{CO}$-eq./ tonne wet biomass) and grassy biomass to produce growth media (-229 $\mathrm{kg} \mathrm{CO}_{2}$-eq./tonne wet biomass). In contrast, composting grassy biomass for fertiliser replacement on agricultural fields results in the largest GHG burdens of $62 \mathrm{~kg} \mathrm{CO}_{2}$-eq. / tonne wet biomass. The findings imply that residual biomass from landscape management can contribute to both GHG benefits and burdens, depending on the application. Higher benefits were found for bioenergy than for biomaterial applications. Biomass applications should be chosen with care and consideration of their counterfactuals.
\end{abstract}

Keywords: climate change mitigation, bioenergy, biomaterial, biomass residues, riparian vegetation, floodplain management

\section{Introduction}

Bioenergy and biomaterials may contribute to a reduction in fossil fuel use and the mitigation of climate change (Creutzig et al., 2015). The dedicated production of biomass requires significant amounts of land and water, which can lead to an increase in water scarcity and both direct and indirect effects of land-use change. In many cases, greenhouse gas (GHG) emissions caused by landuse change outweigh the GHG savings of bioenergy production for years to decades (Elshout et al., 2015) or even longer (Searchinger et al., 2008). The use of residual biomass, rather than dedicated biomass production, can avoid negative effects associated with land-use change and water use Creutzig et al., (2015) and is recommend to policymakers Dornburg et al. (2010). Residual biomass includes harvesting and processing residues from agriculture and forestry, animal manure, biogenic waste streams from industry and consumers, and residues of landscape management (Smith et al., 2014). Landscape residues include biomass released during vegetation management in various types 
of landscapes, for example roadside vegetation, pastures and semi-natural landscapes such as floodplains (Pfau, 2015).

Various publications have addressed the GHG emissions of bioenergy produced from residual biomass reporting potential GHG savings in comparison to reference systems, for example woody biomass residues from Italian orchards (Boschiero et al., 2016), forest residues in the UK (Whittaker et al., 2011) and cattle manure (de Azevedo et al., 2017). Several studies compare the climate impacts of biomass usage for different forms of bioenergy or biomaterials. For example, GerssenGondelach et al. (2014) analysed a variety of feedstocks, pre-treatment technologies and applications. The authors calculated avoided GHG emissions and found beneficial results for almost all routes analysed. Kim and Song (2014) compared the recycling of wood waste into either energy or materials and reported GHG savings for both. Recchia et al. (2010) analysed the environmental benefits of energy derived from riparian vegetation in Italy and Boscaro et al. (2018) calculated GHG impacts of using grass obtained from landscape management of riverbanks for biogas production in Italy. Both studies report significant GHG benefits and are discussed further in Section 4. No previous studies have investigated the optimal use of residual biomass from riparian vegetation, or from landscape management in general, comparing various bioenergy and biomaterial applications from a GHG emission perspective.

This study quantified the potential contribution of residual biomass available from vegetation management in floodplains of the Dutch Rhine delta to climate change mitigation through bioenergy and biomaterial production. The Dutch Rhine delta is densely populated and has a relatively high flood risk due to expected increases in peak river discharges as a result of climate change (Middelkoop et al., 2001). This has led to extensive and ongoing flood risk management (Kabat et al., 2005), including frequent riparian vegetation management to increase the water conveying capacity of floodplains (Straatsma and Kleinhans, 2018). Vegetation management based on cyclic rejuvenation can be applied to achieve optimal biomass removal (Baptist et al., 2004), while at the same time yielding a continuous biomass supply (Koopman et al., 2018). Vegetation management is costly, giving rise to the idea of residual biomass usage to (partly) repay management costs, while providing a valuable resource for sustainable products.

The goal of this study was to find the lowest net GHG emissions from various applications of residual biomass derived from landscape management (such as energy, material and feed uses). The GHG benefits or burdens of such applications are calculated in comparison with the emissions of their respective conventional energy and material counterparts, which are referred to as counterfactuals (cfl.). The consideration of counterfactual emissions, as proposed in this study, enables the comparison of net GHG emissions across different types of applications (e.g. energy vs. material applications), and can be applied to any source of residual biomass. This study demonstrates how landscape management residues can contribute to climate change mitigation, focusing on thirteen applications of residual biomass from Dutch floodplain management.

\section{Methods}

\subsection{Biomass applications and counterfactuals}

Residual biomass harvested during vegetation management was categorised into: (1) woody biomass from forests and shrubs, and (2) grassy biomass from reeds, herbaceous vegetation and natural grassland (adapted from Koopman et al., 2018). Information on current applications for both types of biomass was collected through semi-structured interviews with water management organisations involved in the management of vegetation in publicly owned areas of Dutch floodplains. These include the executive part of the Dutch Ministry of Infrastructure and Water 
Management, the state forestry service, and several water boards. Some of these interviews were conducted during a parallel study (Bout et al., 2019).

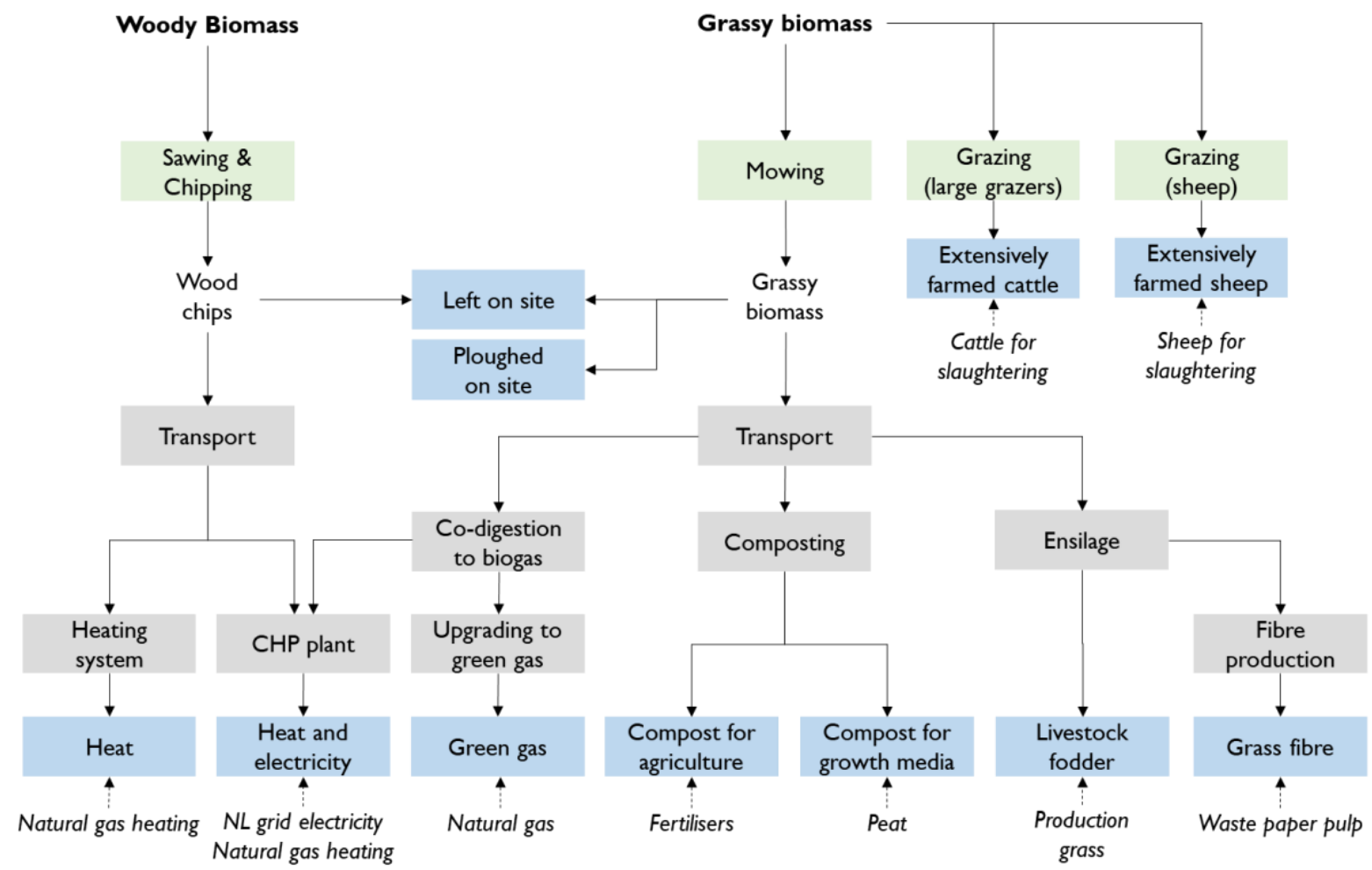

Figure 1: Schematic presentation of biomass applications and counterfactuals analysed in this study. Vegetation management activities are shown in green, transport and processing steps in grey and applications in blue. Counterfactuals are indicated in italic. Both woody and grassy biomass may be left on site or applied in combined heat and power (CHP) installations (grassy biomass after conversion to biogas), resulting in 13 applications.

This inventory revealed a total of thirteen biomass applications that are realised in current practice and can be subdivided into four categories: (1) left or ploughed on site, (2) grazing, (3) energy production and (4) material production. Figure 1 shows the applications, transport and processing steps and counterfactuals. Table 1 provides short descriptions of the applications. An extensive description and rationale for the choice of counterfactuals is included in the Appendix (A1).

Table 1: Description of biomass applications and counterfactuals. Includes the acronyms used in the text, the name of each application, a short description and the counterfactuals. An extensive description and rationale for choice of counterfactuals is included in Appendix A1.

\begin{tabular}{|c|c|c|c|}
\hline Acronym & Application & Description & Counterfactual \\
\hline \multicolumn{4}{|c|}{ Biomass left on site and ploughed on site } \\
\hline WLS & Woody biomass left on site & $\begin{array}{l}\text { Biomass left at vegetation } \\
\text { management location; natural } \\
\text { decomposition }\end{array}$ & $\begin{array}{l}\text { None: non-productive land; no } \\
\text { fertiliser replacement }\end{array}$ \\
\hline GLS & Grassy biomass left on site & $\begin{array}{l}\text { Biomass left at vegetation } \\
\text { management location; natural } \\
\text { decomposition }\end{array}$ & $\begin{array}{l}\text { None: non-productive land; no } \\
\text { fertiliser replacement }\end{array}$ \\
\hline GPoS & $\begin{array}{l}\text { Grassy biomass ploughed } \\
\text { on site }\end{array}$ & $\begin{array}{l}\text { Biomass ploughed on fields to } \\
\text { improve soil quality }\end{array}$ & $\begin{array}{l}\text { None: fresh biomass applied } \\
\text { additionally; no fertiliser } \\
\text { replacement }\end{array}$ \\
\hline \multicolumn{4}{|l|}{ Grazing } \\
\hline GLG & $\begin{array}{l}\text { Grassy biomass grazing } \\
\text { large grazers }\end{array}$ & $\begin{array}{l}\text { Vegetation management by year- } \\
\text { round grazing, } 70 \% \text { cattle }\end{array}$ & $\begin{array}{l}\text { Conventionally farmed cattle: grazers } \\
\text { provide small amounts of organic } \\
\text { meat }\end{array}$ \\
\hline
\end{tabular}




\begin{tabular}{|c|c|c|c|}
\hline GGS & $\begin{array}{l}\text { Grassy biomass grazing } \\
\text { sheep }\end{array}$ & $\begin{array}{l}\text { Vegetation management by herds of } \\
\text { sheep }\end{array}$ & $\begin{array}{l}\text { Conventionally farmed sheep: } \\
\text { grazers provide small amounts of } \\
\text { organic meat }\end{array}$ \\
\hline \multicolumn{4}{|c|}{ Energy production } \\
\hline WH & Woody biomass heat & $\begin{array}{l}\text { Wood chip incineration producing } \\
\text { heat }\end{array}$ & Conventionally produced heat \\
\hline WCHP & Woody biomass CHP & $\begin{array}{l}\text { Wood chip incineration producing } \\
\text { heat and power in combined heat } \\
\text { and power (CHP) plants }\end{array}$ & $\begin{array}{l}\text { Conventionally produced heat and } \\
\text { grid-electricity }\end{array}$ \\
\hline GCHP & Grassy biomass CHP & $\begin{array}{l}\text { Co-digestion of biomass with manure } \\
\text { and subsequent } \mathrm{CHP} \text { application of } \\
\text { biogas }\end{array}$ & $\begin{array}{l}\text { Conventionally produced heat and } \\
\text { grid-electricity }\end{array}$ \\
\hline GGG & Grassy biomass green gas & $\begin{array}{l}\text { Co-digestion of biomass with manure } \\
\text { and subsequent upgrading to green } \\
\text { gas }\end{array}$ & Natural gas \\
\hline \multicolumn{4}{|c|}{ Material production } \\
\hline GCA & $\begin{array}{l}\text { Grassy biomass } \\
\text { composting for agriculture }\end{array}$ & $\begin{array}{l}\text { Composting of biomass and } \\
\text { application on agricultural fields to } \\
\text { improve soil quality }\end{array}$ & Artificial fertilisers \\
\hline GCG & $\begin{array}{l}\text { Grassy biomass } \\
\text { composting for growth } \\
\text { media }\end{array}$ & $\begin{array}{l}\text { Composting of biomass and use in } \\
\text { production of growth media }\end{array}$ & Peat \\
\hline GFo & Grassy biomass fodder & $\begin{array}{l}\text { Ensilage of biomass and use as } \\
\text { livestock fodder }\end{array}$ & Organic production grass \\
\hline $\mathrm{GFi}$ & Grassy biomass fibres & $\begin{array}{l}\text { Extraction of fibres and application in } \\
\text { cardboard production }\end{array}$ & Pre-treated waste paper pulp \\
\hline
\end{tabular}

\subsection{Greenhouse gas emissions}

The GHG emissions in $\mathrm{kg} \mathrm{CO}_{2}$-eq / tonne wet biomass $\left(\mathrm{t}_{\mathrm{wb}}\right)$ of the different applications were calculated as the difference between emissions linked with the biomass application and avoided emissions of counterfactuals $\left(\varepsilon_{c}\right)$ :

$\varepsilon_{\text {total }}=\varepsilon_{V M}+\varepsilon_{T}+\varepsilon_{P}+\varepsilon_{B}+\varepsilon_{D}+\varepsilon_{R}-\varepsilon_{C}$

Emissions of biomass applications included vegetation management activities $\left(\varepsilon_{\mathrm{VM}}\right)$, transport of biomass to processing location $\left(\varepsilon_{\mathrm{T}}\right)$, processing $\left(\varepsilon_{\mathrm{P}}\right)$, biogenic $\mathrm{CO}_{2}$ emissions $\left(\varepsilon_{\mathrm{B}}\right)$, decomposition emissions $\left(\varepsilon_{\mathrm{D}}\right)$ and ruminant $\mathrm{CH}_{4}$ emissions $\left(\varepsilon_{\mathrm{R}}\right)$. Input parameters for calculations were based on literature, data from Ecoinvent v3 LCl database using the IPCC 2013 GWP100a method (Wernet et al., 2016), personal communication with stakeholders and own calculations. Default values for parameters for which ranges were found in literature were calculated as the geometric mean of all available data. For skewed distributions, as is the case for the applied input parameters, the geometric mean describes the central tendency of the data. Specific calculations for each application are shown in the Appendix (A2.). All input parameters and their sources are shown in Tables A1 and A2.

GHG emissions from vegetation management were calculated as:

$\varepsilon_{V M}=\sum_{M U} H P \times F_{M U} \times E_{M U}$

where $H P$ is the harvesting pace for woody or grassy biomass ( $\mathrm{h} / \mathrm{t}_{\mathrm{wb}}$ harvested), $F_{M U}$ the fraction of machine use for each type of machine (dimensionless) and $E_{M U}$ the emission factors for each type of machine used ( $\mathrm{kg} \mathrm{CO}_{2}$-eq. / h), including construction and fuel consumption. Data on machine use and fuel consumption were based on reports from contractors conducting vegetation management in the Netherlands (see A2 and Table A1).

Transport GHG emissions were calculated as:

$\varepsilon_{T}=2 \times T D \times E_{T}$ 
where $T D$ is the biomass transport distance $(\mathrm{km})$ for each application and $E_{T}$ is the emission factor for transport with lorries $\left(\mathrm{kg} \mathrm{CO}_{2}\right.$-eq. $\left./ \mathrm{tkm}\right) . E_{\mathrm{T}}$ is derived from Ecoinvent and based on average load factors from the Tremove model v2.7b (De Ceuster et al., 2009) and EcoTransIT (Knörr et al., 2011) report. The emission is based on partial loading (83\% of capacity) and empty return trips. The oneway transport distances were doubled to account for the distance covered by lorries to the floodplain and from the processing locations. For $T D$ the minimum transport distance driving routes were determined for lorries to transport biomass from floodplains to biomass processing locations. In total, 95 processing locations in the Netherlands were identified from several sources (details in Table A3) and subsequently manually geocoded. Minimum transport distances for driving routes were calculated by means of the Google maps programming interface. The 179 floodplain sections in the study area, described in Section 2.3, provided the starting points and the 95 biomass processing locations gave the destination points, giving a total of 17,005 routes. Subsequently, the shortest route was selected for each floodplain section to each processing location with a specific biomass application (example shown in Figure 2). Transport distances were summarised by calculating the mean over all floodplain sections.

Processing GHG emissions were derived as:

$\varepsilon_{P}=\sum_{p} A_{p} \times E_{p}$

where $A_{P}$ is the amount of each product $P$ produced (e.g. $\mathrm{kg} / \mathrm{t}_{\mathrm{wb}}$ or $\mathrm{MJ} / \mathrm{t}_{\mathrm{wb}}$ ) and $E_{P}$ is the emission factor for production of product $P$ (e.g. $\mathrm{kg} \mathrm{CO}_{2}$-eq. / $\mathrm{kg}$ or kg $\mathrm{CO}_{2}$-eq. / MJ). These emissions can include both upstream emissions (e.g. construction of processing installations) and processing emissions (e.g. energy consumption of processing installations and emissions occurring during processing), depending on the application (see A2).

Biogenic carbon emissions were derived as:

$\varepsilon_{B}=E_{B} \times G W P_{b i o}$

where $E_{B}$ is the biogenic $\mathrm{CO}_{2}$ emission of woody or grassy biomass ( $\mathrm{kg}$ biogenic $\mathrm{CO}_{2} / \mathrm{t}_{\mathrm{wb}}$ ) and $G W P_{\text {bio }}$ the global warming potential of $\mathrm{CO}_{2}$ emissions from biomass combustion ( $\mathrm{kg}$ fossil $\mathrm{CO}_{2}$-eq. / $\mathrm{kg}$ biogenic $\mathrm{CO}_{2}$ ), as developed by Cherubini et al. (2011). A one-year rotation time was assumed for grassy biomass, based on the annual vegetation management required by flood safety regulations, resulting in a $G W P_{\text {bio }}$ and $\varepsilon_{B}$ of zero for all grassy biomass applications. Rotation times for woody biomass vary according to location: five years for high flow zones and 20 years for low flow zones. The GWP bio of woody biomass was calculated based on the proportion of woody biomass increments in both flow zones, as described in Section 2.3.

Decomposition GHG emissions refer to:

$\varepsilon_{D}=E_{N 2 O} \times G W P_{N 2 O}+E_{C H 4} \times G W P_{C H 4}$

where $E_{\mathrm{N} 2 \mathrm{O}}$ and $E_{\mathrm{CH} 4}$ are $\mathrm{N}_{2} \mathrm{O}$ and $\mathrm{CH}_{4}$ emissions occurring during natural decay of biomass $\left(\mathrm{kg} / \mathrm{t}_{\mathrm{wb}}\right)$ and $G W P_{N 2 O}$ and $G W P_{\mathrm{CH}_{4}}$ the global warming potentials of $\mathrm{N}_{2} \mathrm{O}$ and $\mathrm{CH}_{4}\left(\mathrm{~kg} \mathrm{CO}_{2}\right.$-eq. $\left./ \mathrm{kg} \mathrm{CH} \mathrm{CH}_{4}\right)$. For woody biomass, $E_{\mathrm{N} 2 \mathrm{O}}$ and $E_{\mathrm{CH} 4}$ were calculated based on the fractions of $\mathrm{N}$ emitted as $\mathrm{N}_{2} \mathrm{O}$ and $\mathrm{C}$ as $\mathrm{CH}_{4}$.

Ruminant emissions are equal to:

$\varepsilon_{R}=E_{R} \times A R \div B M P_{G} \times 365$ days $\times G W P_{C H 4}$

where $E_{R}$ are the ruminant $\mathrm{CH}_{4}$ emissions of grazers $\left(\mathrm{kg} \mathrm{CH}_{4} /\right.$ head /day), $A R$ is the number of animals required to maintain one hectare for a year (head / ha), $B M P_{G}$ is the grassy biomass production per ha ( $\mathrm{t}_{\mathrm{wb}} / \mathrm{ha}$ ) and the $G W P_{\mathrm{CH} 4}$ the global warming potential of $\mathrm{CH}_{4}\left(\mathrm{~kg} \mathrm{CO}\right.$-eq. / $\mathrm{kg} \mathrm{CH} \mathrm{CH}_{4}$ ). The grassy biomass production per ha was calculated by dividing the grassy biomass produced in each section, 
as described in methods Section 2.3 , by the surface areas of the same section. Subsequently, the average for all sections was calculated.

Counterfactual emissions were calculated as:

$\varepsilon_{C}=\sum_{C} A_{C} \times E_{C}$

where $A_{c}$ is the amount of each counterfactual $C$ avoided (e.g. $\mathrm{kg} / \mathrm{t}_{\mathrm{wb}}$ ) and $E_{C}$ is the emission of the production of each counterfactual (e.g. kg CO2-eq. / kg). See appendix A2 for further details on the counterfactual GHG emission calculations.

\subsection{Study area and biomass production}

The overall climate mitigation potential of residual biomass was calculated over the terrestrial floodplain area of the three Rhine river distributaries in the Netherlands (Figure 2). The total embanked area amounts to $440 \mathrm{~km}^{2}$, of which $62 \%$ is vegetated. Meadows dominate the land cover, but recent nature rehabilitation programmes have led to an increase in areas with herbaceous vegetation, shrubs and forests.

Biomass from publicly owned areas was distinguished from those that are owned privately. The public areas are managed by water management or other governmental organisations. These organisations are becoming increasingly interested in using landscape residues sustainably. Biomass from privately-owned areas was included to give an impression of the overall potential on a landscape scale.

The mean biomass production values per floodplain section were calculated based on three spatial datasets. Firstly, the entitled person per cadastral parcel ([dataset] Kadaster, 2017) was classified as public, or private based on the name. Secondly, vegetation limitation data (Rijkswaterstaat, 2014) divided the floodplain area into hydrodynamic flow zones defining the conveyance capacity. In high flow zones, the vegetation is limited to types with a low hydrodynamic roughness, e.g. meadows and agriculture. Shrubs, reeds and forests are allowed in low flow zones. Thirdly, ecotope data provided definitions for vegetation classes. Ecotopes are homogeneous landscape units based on specific hydro-morphological, geomorphological, ecological and land-use characteristics (Van der Molen et al., 2003). A schematic map of the 179 floodplain sections provided the spatial aggregation units (Figure 2). The biomass production was calculated according to Koopman et al. (2018). Four biomass production values were determined for each floodplain section using spatial overlays: (1) public-low flow, (2) public-high flow, (3) private-low flow and (4) private high flow. The four biomass production values were summed over all floodplain sections to determine the total biomass production for each combination in tonne dry matter (tDM). A final conversion was applied to wet biomass $\left(t_{w b}\right)$ based on the dry matter (DM) fraction of woody and grassy biomass (Table A1). 


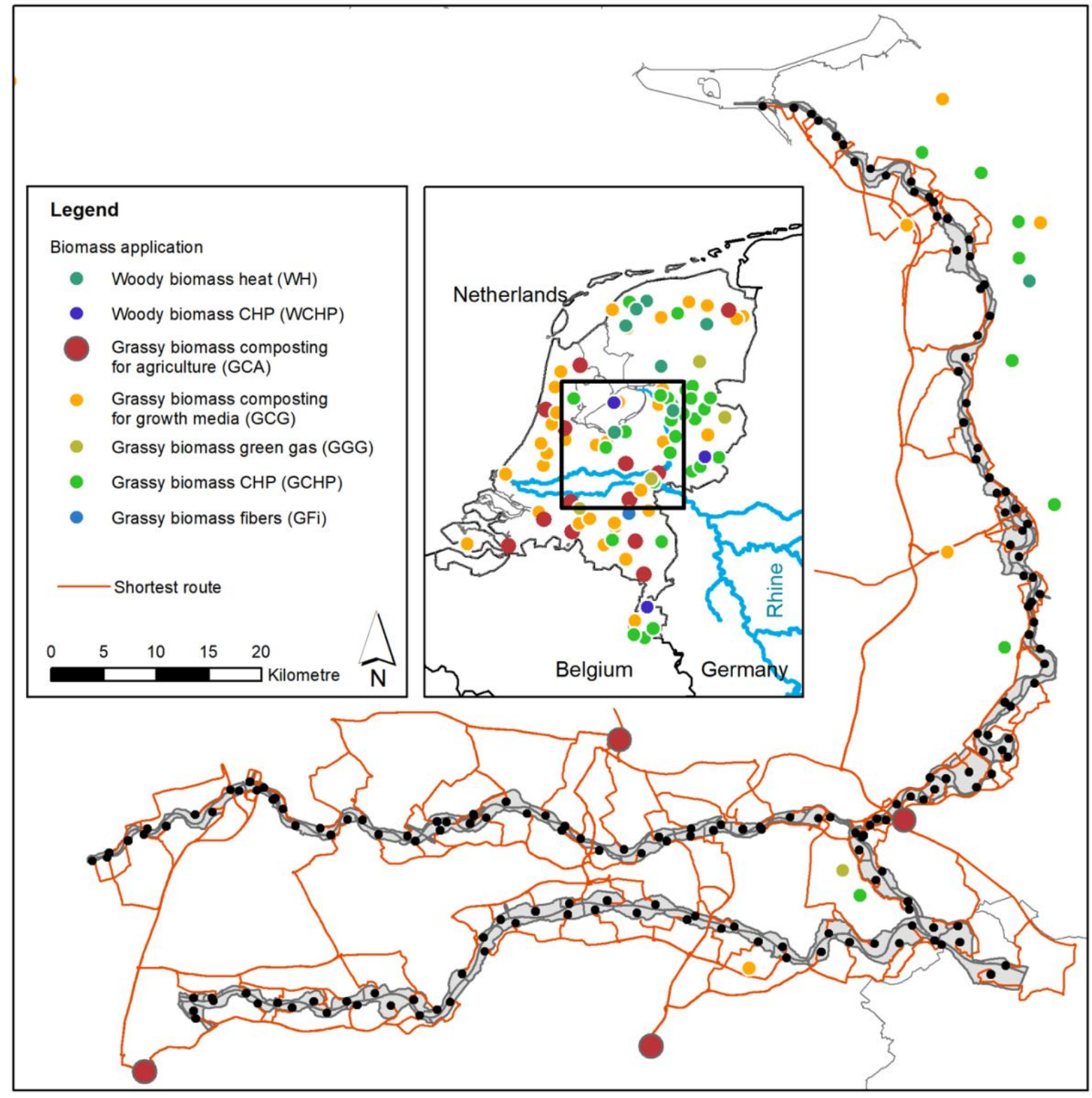

Figure 2: Schematic map of the study area. Showing the floodplain sections of the Dutch Rhine distributaries Waal, Nederrijn-Lek and IJssel (grey), the processing locations for different biomass applications and an example of the shortest driving routes between floodplains and grassy biomass composting sites for agriculture.

\subsection{Sensitivity analysis}

A sensitivity analysis on the GHG emissions of different biomass applications was performed. Table 2 shows the parameters analysed in the sensitivity analysis. Calculations and sources for all parameters are presented in Table A1. The total GHG emission in $\mathrm{kg} \mathrm{CO}_{2}$-eq. / $\mathrm{t}_{\mathrm{wb}}$ of each application was calculated separately for the default, minimum and maximum values of each parameter. The resulting GHG emission outcomes were then plotted against the parameter variation expressed as a percentage, where the default represents $100 \%$. 
Table 2: Parameters analysed during sensitivity analysis. For each parameter, the use in the equations presented in Section 2.2 and the default value used in the calculation is shown, together with the minimum and maximum value used during the sensitivity analysis. Calculations and sources for all parameter values can be found in Table A1.

\begin{tabular}{|c|c|c|c|c|c|c|}
\hline & Parameter & Equation & Unit & $\begin{array}{r}\text { Default } \\
\text { value }\end{array}$ & $\begin{array}{r}\text { Minimum } \\
\text { value }\end{array}$ & $\begin{array}{r}\text { Maximum } \\
\text { value }\end{array}$ \\
\hline \multirow[t]{2}{*}{1.} & Harvesting pace woody biomass & (2); $H P$ & $\mathrm{~h} / \mathrm{t}_{\mathrm{wb}}$ harvested & 0.91 & 0.31 & 2.67 \\
\hline & Harvesting pace grassy biomass & (2); $H P$ & $\mathrm{~h} / \mathrm{t}_{\mathrm{wb}}$ harvested & 0.57 & 0.42 & 0.77 \\
\hline 2. & Biomass transport distance & (3); $T D$ & $\mathrm{~km}$ & Table A1 & $\begin{array}{l}50 \% \text { of } \\
\text { default }\end{array}$ & $\begin{array}{r}200 \% \text { of } \\
\text { default }\end{array}$ \\
\hline 3. & Ploughing required for GPoS & (4); part of $A_{P}$ & ha $/ t_{w b}$ & 0.2 & $\begin{array}{l}50 \% \text { of } \\
\text { default }\end{array}$ & $\begin{array}{r}200 \% \text { of } \\
\text { default }\end{array}$ \\
\hline 4. & Biogas yield during co-digestion & (4); part of $A_{P}$ & $m^{3} / t_{w b}$ & 70.2 & 60 & 77 \\
\hline 5. & $\begin{array}{l}\text { Calorific value woody biomass (as } \\
\text { received) }\end{array}$ & $\begin{array}{l}\text { (4); part of } A_{p} \\
\text { (8); part of } A_{C}\end{array}$ & $\mathrm{MJ} / \mathrm{t}_{\mathrm{wb}}$ & 8030 & 7400 & 10120 \\
\hline 6. & $\begin{array}{l}\text { WCHP electric conversion } \\
\text { efficiency }\end{array}$ & $\begin{array}{l}\text { (4); part of } A_{P} \\
\text { (8); part of } A_{C}\end{array}$ & dimensionless & 0.16 & 0.16 & 0.3 \\
\hline \multirow[t]{3}{*}{7.} & $\begin{array}{l}\mathrm{CH}_{4} \text { emissions of WLS } \\
\text { decomposition; fraction of } \mathrm{C} \\
\text { emitted as } \mathrm{CH}_{4}\end{array}$ & (6); part of $E_{C H 4}$ & dimensionless & 0.01 & 0.01 & 0.022 \\
\hline & $\begin{array}{l}\mathrm{N}_{2} \mathrm{O} \text { emissions of WLS } \\
\text { decomposition; fraction of } \mathrm{N} \\
\text { emitted as } \mathrm{N}_{2} \mathrm{O}\end{array}$ & (6); part of $E_{N 2 O}$ & dimensionless & 0.01 & 0.01 & 0.016 \\
\hline & $\begin{array}{l}\mathrm{N}_{2} \mathrm{O} \text { emissions of GLS and GPoS } \\
\text { decomposition }\end{array}$ & $(6) ; E_{N 2 O}$ & $\mathrm{~kg} \mathrm{~N} \mathrm{~N}_{2} \mathrm{O} \mathrm{t}_{\mathrm{wb}}$ & 0.07 & $\begin{array}{l}50 \% \text { of } \\
\text { default }\end{array}$ & $\begin{array}{r}200 \% \text { of } \\
\text { default }\end{array}$ \\
\hline \multirow[t]{4}{*}{8.} & $\mathrm{CH}_{4}$ emissions per sheep & (7); $E_{R}$ & $\begin{array}{l}\mathrm{kg} \mathrm{CH}_{4} / \text { grazer / } \\
\mathrm{d}\end{array}$ & 0.019 & 0.014 & 0.024 \\
\hline & $\mathrm{CH}_{4}$ emissions per large grazer & (7); $E_{R}$ & $\begin{array}{l}\mathrm{kg} \mathrm{CH}_{4} / \text { grazer / } \\
\mathrm{d}\end{array}$ & 0.19 & 0.13 & 0.27 \\
\hline & Sheep required to maintain one ha & (7); $A R$ & grazers / ha & 5.24 & 3.79 & 7.22 \\
\hline & $\begin{array}{l}\text { Large grazers required to maintain } \\
\text { one ha }\end{array}$ & (7); $A R$ & grazers / ha & 1.41 & 0.4 & 2 \\
\hline 9. & Fertiliser replacement of GCA & (8); part of $A_{C}$ & $\mathrm{~kg} \mathrm{~N} / \mathrm{t}_{\mathrm{wb}}$ & 0.89 & 0.5 & 1.92 \\
\hline \multirow[t]{2}{*}{10.} & $\begin{array}{l}\text { GHG emissions of GCG } \\
\text { counterfactual growth media from } \\
\text { peat }\end{array}$ & $(8) ; E_{C}$ & $\begin{array}{l}\mathrm{kg} \mathrm{CO} 2 \text {-eq. / } \mathrm{t} \\
\text { peat }\end{array}$ & 811.4 & 550 & 1197 \\
\hline & Peat replacement of GCG & (8); part of $A_{C}$ & $\begin{array}{l}\mathrm{t} \text { peat } / \mathrm{t} \\
\text { compost }\end{array}$ & 0.67 & 0.2 & 1 \\
\hline 11. & $\begin{array}{l}\text { GHG emissions of GFi } \\
\text { counterfactual fibre from waste } \\
\text { paper }\end{array}$ & $(8) ; E_{C}$ & $\begin{array}{l}\mathrm{kg} \mathrm{CO} \mathrm{CO}_{2} \text {-eq. / } \mathrm{t} \\
\text { paper pulp }\end{array}$ & 211.2 & 134.14 & 298.64 \\
\hline 12. & $\begin{array}{l}\text { GHG-intensity of counterfactual } \\
\text { electricity WCHP and GCHP }\end{array}$ & (8); part of $E_{C}$ & $\mathrm{~kg} \mathrm{CO}$-eq. / MJ & 0.15 & 0.12 & 0.29 \\
\hline
\end{tabular}

The sensitivity of the following parameters was considered:

1. The harvesting pace of both woody and grassy biomass shows large variations in literature and has a large influence on harvesting emissions, which are part of almost all applications.

2. Biomass transport distances were based on the current minimum distance between floodplains and processing locations, as described in Section 2.2. Distances could change when roads or processing locations are altered or added. Variations of a factor 0.5 and 2 were investigated.

3. The ploughing required to apply one tonne of wet biomass on agricultural soils has a large variability in practice and documentation is limited. Variations of a factor 0.5 and 2 were explored.

4. Biogas yields during co-digestion of grassy biomass strongly influence results and are variable due to different feedstock mixtures and fermenter conditions.

5. The calorific value of wood varies with moisture content, which depends on field and (passive) drying conditions. Calorific values for $40-50 \%$ moisture contents were analysed.

6. The default electric conversion efficiency of woody biomass CHP installations is based on the current situation. However, larger-scale electricity production can result in higher efficiencies 
and greater avoided emissions. A scenario of CHP with higher electricity output and higher efficiency was explored.

7. $\mathrm{CH}_{4}$ and $\mathrm{N}_{2} \mathrm{O}$ emissions relating to natural decomposition of biomass are highly variable and little data is available. Because this study considered non-piled wood with aerobic decomposition, default woody biomass decomposition emissions were based on minimum emissions of piled wood. This assumption was tested by applying a typical value for piled wood as a maximum value. Similar variation is expected for decomposition of grassy biomass (GLS and GPoS). Variations of a factor of 0.5 and 2 were investigated.

8. Both the number of grazers required to maintain one ha of land and the $\mathrm{CH}_{4}$ emissions per grazer affect the GHG emissions and have a substantial natural variability. The maximum and minimum calculated for the parameter based on different sources was analysed.

9. Large variability was observed in literature for data concerning $\mathrm{N}$ fertiliser replacement of compost, so the overall range described by different sources was analysed.

10. Regarding GCG, large variations were described in literature for both the amount of peat replaced per $t$ compost and the GHG emissions of the counterfactual (growth media produced using peat). Both are influential parameters.

11. The GHG emission of the GFi counterfactual (fibre produced from waste paper) is uncertain due to lack of data. The actual GHG emissions of fibre production (including waste paper collection, sorting and re-pulping) are unknown. The GHG emission of recycled paper minus the electricity for the papermaking step was used but this could be a conservative estimate. The geomean of both parameters was used as default value and the overall range of values was explored here.

12. The WCHP and GCHP counterfactuals apply the current state of grid-electricity in the Netherlands. Changes in avoided emissions were quantified by applying gas electricity (minimum value) and coal electricity (maximum value), rather than the Dutch grid mix (default).

\section{Results}

\subsection{Greenhouse gas emissions and avoided emissions of residual biomass applications}




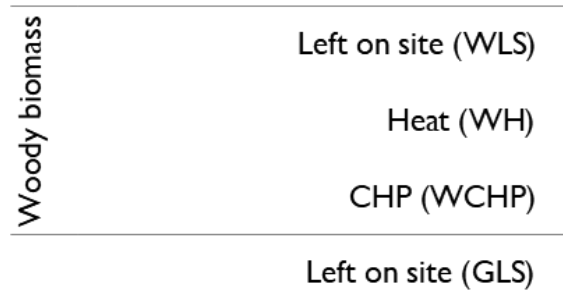

Ploughed on site (GPoS)

Green gas (GGG)

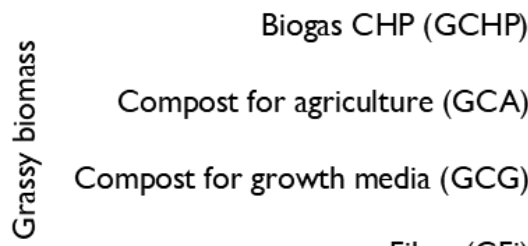

Fibre (GFi)

Livestock Fodder (GFo)

Grazing sheep (GGS)

Grazing large grazers (GLG)

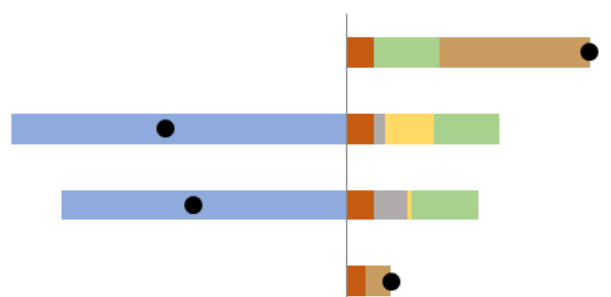

$-400$

$-300$

$-200$

100

200

$\mathrm{GHG}$ emissions or savings ( $\mathrm{kg} \mathrm{CO}$-eq./tonne wet biomass used)

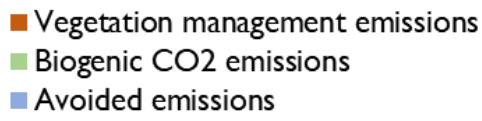

Processing emissions

- Ruminant $\mathrm{CH} 4$ emissions

- Net GHG emissions

Figure 3 shows the GHG emissions and savings for each application in $\mathrm{kg} \mathrm{CO}_{2}$-eq. / $\mathrm{t}_{\mathrm{wb}}$ and the total net GHG emissions, representing the overall GHG burden or benefit that can be achieved with each tonne of residual biomass. Biomass left or ploughed on site and biomass removal by grazing animals both result in net GHG burdens. All energy applications provide GHG benefits, ranging from - 132 to $112 \mathrm{~kg} \mathrm{CO}$-eq. $/ \mathrm{t}_{\mathrm{wb}}$ for woody biomass (WH and $\mathrm{WCHP}$ ), and from -56 to $-0.5 \mathrm{~kg} \mathrm{CO}$-eq. $/ \mathrm{t}_{\mathrm{wb}}$ for grassy biomass (GCHP and GGG). Note that the conversion of biogas to green gas, which more than doubles the processing emission, appeared not to be particularly worthwhile from a GHG perspective because the use of biogas in CHP installations achieves much higher GHG benefits. Material applications of grassy biomass for fibre and fodder achieve GHG benefits of -43 and $-3 \mathrm{~kg}$ $\mathrm{CO}_{2}$-eq. $/ \mathrm{t}_{\mathrm{wb}}$. Depending on the final product, composting results in both the greatest $\mathrm{GHG}$ benefit and the highest GHG burden for grassy biomass with values of -229 and $62 \mathrm{~kg} \mathrm{CO}$-eq. / $\mathrm{t}_{\mathrm{wb}}$ (GCG and GCA). This is mainly due to the large difference in counterfactual emissions. Replacing peat in growth media with compost achieves great GHG benefits. Applying compost in agriculture replaces only moderate amounts of fertilisers, which results in small GHG savings from avoided fertiliser production and application. In practice, each tonne of biomass delivered to a composting installation will contribute to both products. Assuming $18 \%$ GCG and $82 \%$ GCA application (based on BVOR, 2016), the combined outcome will be $9 \mathrm{~kg} \mathrm{CO}$-eq. / $\mathrm{t}_{\mathrm{wb}}$. Biogenic $\mathrm{CO}_{2}$ emissions contribute significantly to woody biomass application emissions, averaging $40 \%$. Transport and vegetation management emissions each contribute an average of $21 \%$ to all applications featuring these emissions. 


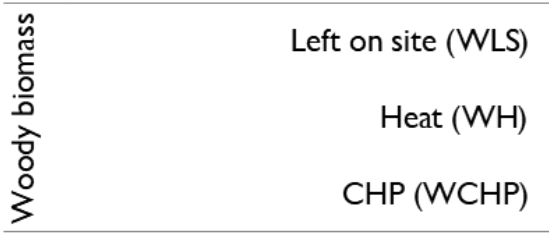

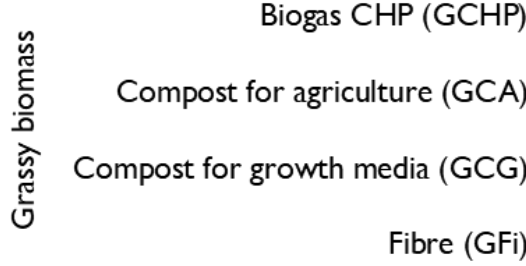

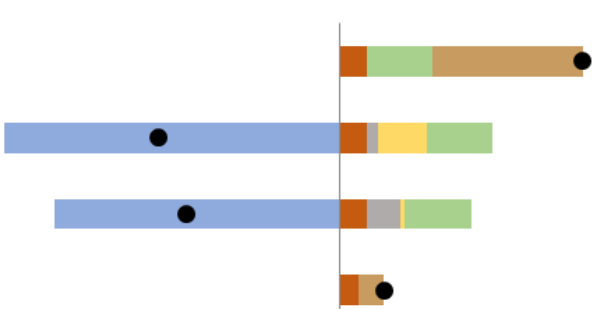

$\mathrm{GHG}$ emissions or savings ( $\mathrm{kg} \mathrm{CO}$-eq./tonne wet biomass used)

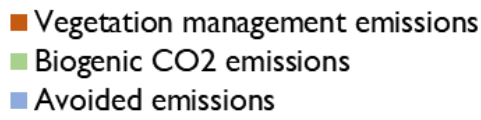

Avoided emissions

\author{
Transport emissions \\ Decomposition emissions \\ - Net GHG emissions
}

Processing emissions

Ruminant $\mathrm{CH} 4$ emissions

Figure 3: GHG emissions and savings of current residual biomass applications at biomass scale. GHG emissions from various sources are presented as positive values. GHG savings, achieved through the replacement of counterfactuals, are presented as negative values. Net GHG emissions are the sum of emissions and savings and are presented as black dots.

\subsection{Climate change mitigation potential of residual biomass use}

The overall potential for residual biomass derived from the Rhine floodplains to contribute to climate change mitigation differed widely (Figure 4). It was calculated that 49 and 93 kilotons (kt) of woody biomass, and 322 and $583 \mathrm{kt}$ of grassy biomass are produced per year on publicly-owned areas and over the whole study area. $86 \%$ of all residual biomass is grassy biomass and as a result, grassy biomass applications with overall GHG benefits achieve a higher climate change mitigation potential in comparison to woody biomass applications at landscape scale. 


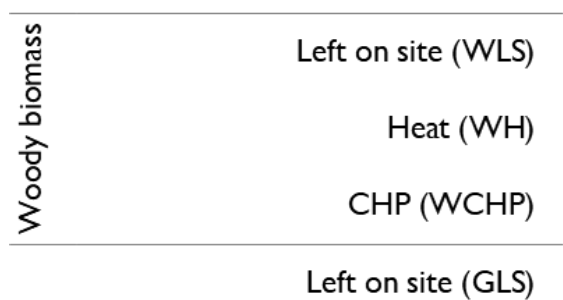

Ploughed on site (GPoS)

Green gas (GGG)

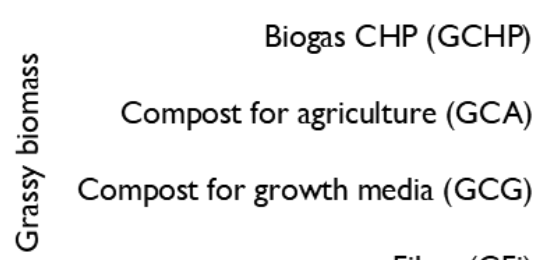

Fibre (GFi)

Livestock Fodder (GFo)

Grazing sheep (GGS)

Grazing large grazers (GLG)

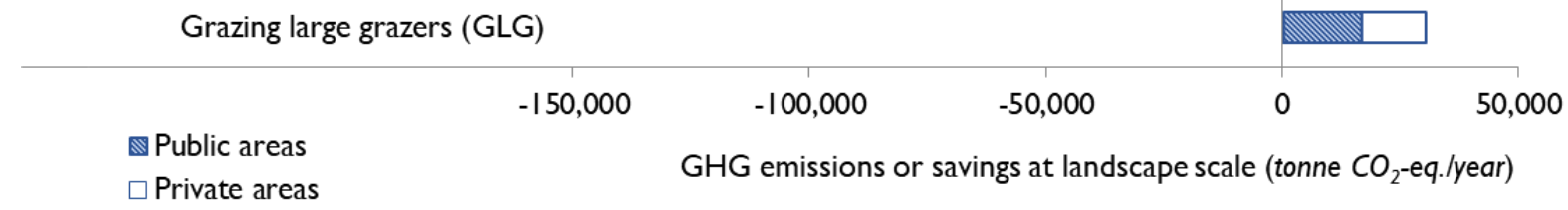

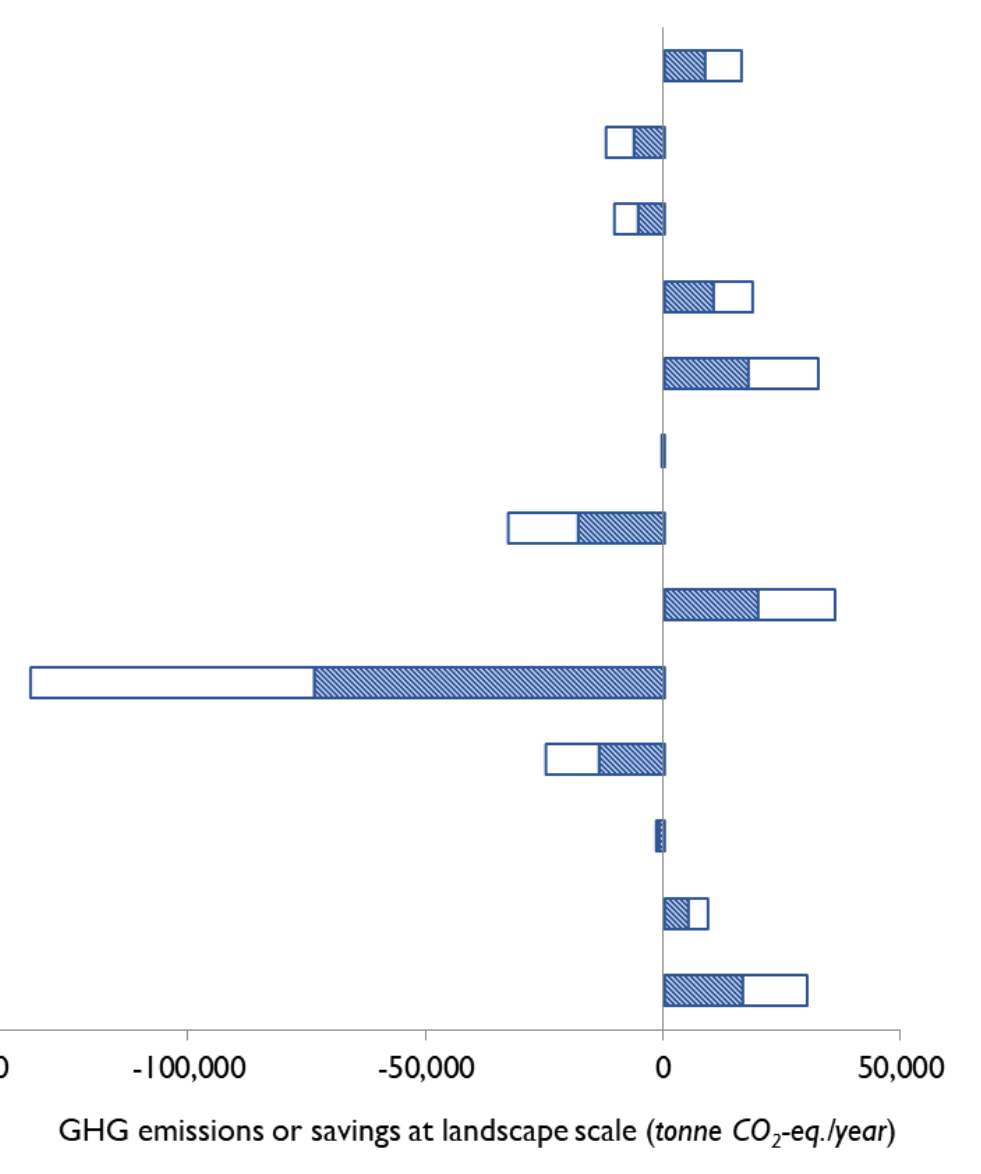

Figure 4: GHG emissions and savings of current residual biomass applications at landscape scale. The total GHG emissions or savings of each application, multiplied with the biomass available in the study area (cf. Figure 2) each year are shown. Biomass availability from publicly and privately-owned areas was distinguished which together represent the entire study area.

The overall climate change mitigation potential depends not only on the amount of GHG emissions saved by beneficial applications, but also on their processing capacities. Table 3 shows the current processing capacities of the five applications resulting in clear GHG savings and the overall potential for processing biomass from the study area, based on a combination of the current capacity and the available residual biomass in the study area. Constraints resulting from current workload of these installations are not considered, assuming in the future additional capacity could be added if more landscape residues were to be processed. Table 3 shows that the total amount of residual grassy and woody biomass available annually would not exceed the maximum processing capacity of the most GHG-beneficial applications, WH and GCG. If public organisations ensured that their biomass was processed for the most GHG beneficial applications, a maximum contribution to climate change mitigation of 6.4 and $73.6 \mathrm{kt} \mathrm{CO}_{2}$-eq. / y could be achieved for woody and grassy biomass. If all biomass from the whole study area were applied for the most GHG beneficial applications, a maximum saving of $145 \mathrm{kt} \mathrm{CO}$-eq. / y could be achieved. These maximum savings are based on the usage of all available woody and grassy biomass for the most GHG-beneficial applications at their maximum processing capacities. A comparison of applications featuring the highest GHG benefits with those with the highest GHG burdens reveals a difference of $15.0 \mathrm{kt} \mathrm{CO}_{2}$-eq. / y for woody biomass and $28.5 \mathrm{kt} \mathrm{CO}$-eq. / y for grassy biomass from publicly-owned areas and 93.5 and $169 \mathrm{kt}$ $\mathrm{CO}_{2}$-eq. / $\mathrm{y}$ for the whole study area. 
Table 3 shows that WH has the highest potential product output of all energy applications despite the limited availability of wood. WCHP and GCHP are limited by current processing capacity because there are only few WCHP installations and most biogas installations are not equipped to process grass as a co-product. Potential for GCG is large, but the large volumes of garden and kitchen wastes currently processed will limit the capacity to process landscape residues in practice.

Table 3: Current processing capacities of the five applications with clear GHG savings in the Netherlands. Capacities are based on data from existing installations, see Table A3. The potential to process biomass from the study area is based on a combination of the current capacity of the applications and the available residual biomass in the study area. The lowest of these values defines the potential to process. The last two columns show the maximum product output from the study area and a comparison with reference markets.

\begin{tabular}{|c|c|c|c|c|}
\hline Application & $\begin{array}{l}\text { Current capacity in } \\
\text { kt wet biomass / y }\end{array}$ & $\begin{array}{r}\text { Potential to process } \\
\text { biomass from study area } \\
\text { in kt wet biomass / y }\end{array}$ & $\begin{array}{r}\text { Maximum } \\
\text { product output }\end{array}$ & $\begin{array}{l}\text { Market comparison of } \\
\text { maximum product output }\end{array}$ \\
\hline WH & $141^{\mathrm{a}}$ & 93 & $674 \mathrm{TJ}_{\text {th }} / \mathrm{y}$ & 16,042 Dutch households ${ }^{\mathrm{e}}$ \\
\hline WCHP & $57^{a}$ & 57 & $\begin{array}{r}25 \mathrm{TJ}_{\mathrm{el}} / \mathrm{y} \\
242 \mathrm{TJ}_{\mathrm{th}} / \mathrm{y}\end{array}$ & $\begin{array}{l}\text { 2,323 Dutch households }{ }^{\mathrm{e}} \\
5,762 \text { Dutch households }\end{array}$ \\
\hline GCG & $642^{c}$ & 583 & $\begin{array}{r}218 \mathrm{kt} \text { peat } \\
\text { replacement / y }\end{array}$ & $\begin{array}{l}91 \% \text { of peat in growth media } \\
\text { production in } \mathrm{NL}^{\mathrm{c}}\end{array}$ \\
\hline GCHP & $14^{b}$ & 14 & $\begin{array}{r}8 \mathrm{TJ}_{\mathrm{el}} / \mathrm{y} \\
12 \mathrm{TJ}_{\mathrm{th}} / \mathrm{y}\end{array}$ & $\begin{array}{l}790 \text { Dutch households } \\
290 \text { Dutch households }\end{array}$ \\
\hline GFi & $60^{d}$ & 60 & 29 kt fibre / y & $\begin{array}{l}0.5 \% \text { of recycled paper use in } \\
\mathrm{NL}^{\mathrm{f}}\end{array}$ \\
\hline
\end{tabular}

${ }^{\text {a }}$ Calculation based on the identified processing locations (described in Table A3) and data from RVO (2018)

${ }^{b}$ Calculation based on data from personal communication with several companies running biogas CHPs

c Calculation based on market data from BVOR (2016)

${ }^{d}$ Calculation based on data from personal communication with a grass fibre producing company

e Calculation based on household energy consumption data from milieu centraal (2018)

${ }^{f}$ Calculation based on data on recycled paper products in the Netherlands (Stichting PRN, 2016), assuming 1 tDM fibre

replaces $1 \mathrm{t}$ of recycled paper

\subsection{Sensitivity to parameter variability and data uncertainties}

The sensitivity analysis (Figure 5) shows that the results of this study are robust, except in four cases where a relatively large sensitivity is observed. Firstly, GHG emissions from biomass decomposition are highly sensitive to the share of decomposition taking place under anaerobic conditions, releasing $\mathrm{CH}_{4}$. Under maximum anaerobic conditions, woody biomass decomposition (WLS) could lead to $67 \%$ higher overall GHG emissions per tonne of biomass (Figure 5a). Grassy biomass is thinner and more spread out, and is assumed to decompose aerobically. Secondly, CHP applications are sensitive to CHP efficiency and the level of GHG emissions of the counterfactual electricity production (Figure $5 b)$. When replacing coal-based electricity rather than replacing the default counterfactual (current Dutch grid electricity mix) GHG emission savings increase by $44 \%$ and $54 \%$ for grassy (GCHP) and woody biomass (WCHP). For WCHP, higher efficiencies achieved through upscaling could double GHG emission savings. Thirdly, while the variability in calorific value of wood is low (the minimum value is $8 \%$ lower than the default, the maximum value is $26 \%$ higher), it is highly influential on GHG emissions of WH and WCHP: dryer wood can increase emission savings by $40 \%$ (Figure $5 \mathrm{~b}$ ). Fourthly, net GHG emission savings of GCG are sensitive to the amount of peat replaced and to the GHGintensity of the replaced peat (Figure 5c), both of which are uncertain. GHG savings could be $67 \%$ larger, but also strongly reduced. It is unlikely that GHG savings would become smaller than those of other investigated grassy biomass applications.

The sensitivity of the results to variation in other parameters is more limited. Harvesting pace and transport distance can for instance vary substantially (200-300\%), but change overall emissions per $t_{w b}$ by less than $30 \%$. Only one application, GGG, may alter from slightly GHG-beneficial to a small GHG burden when transport distance increases. The number of grazers and their enteric $\mathrm{CH}_{4}$ 
emissions have a natural variability which affects the net GHG emissions of the grazing applications to a larger degree. Even when considering this variation, net GHG emissions remain relatively stable compared to other applications (Figure 5c).
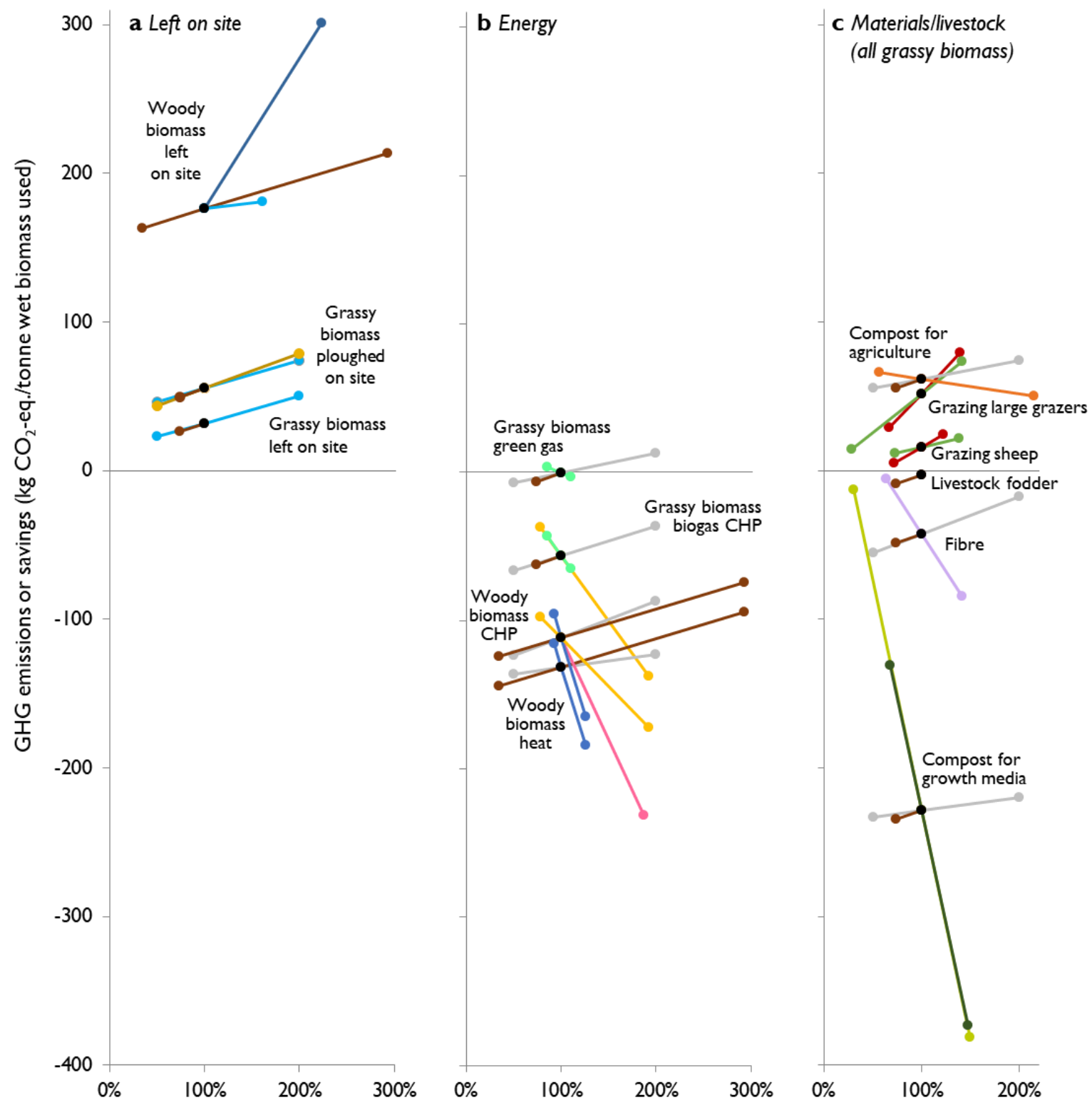

Parameter variation

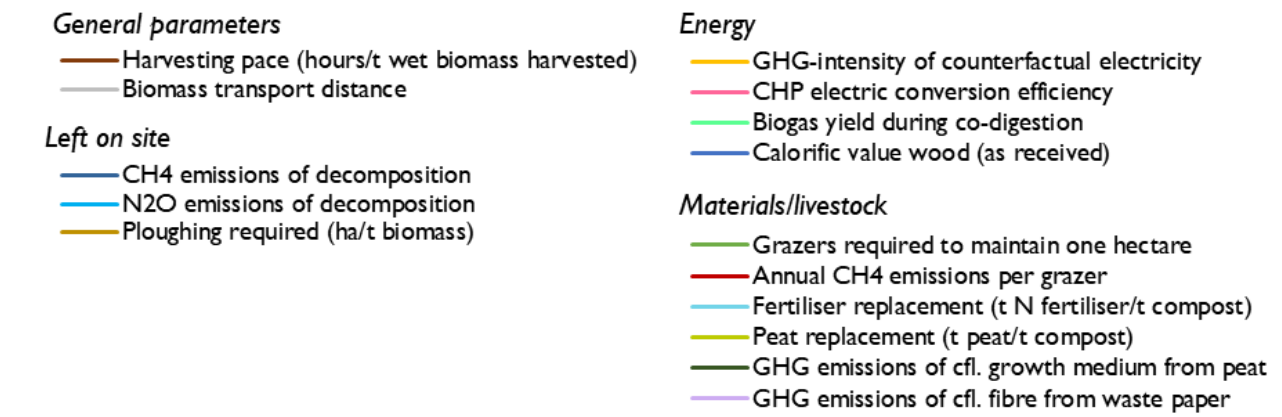

Figure 5: Sensitivity analysis of total GHG emissions of residual biomass applications. Sensitivity to parameter variations is shown based on the percentage of change in the parameter range (x-axis) and the related GHG emissions or savings ( $y$ axis). Parameter ranges are presented in Table 2. 


\section{Discussion}

This study compared the GHG emissions of different applications of residual biomass released during landscape management and provided relevant information on the overall climate change mitigation potential of residual biomass. The approach presented facilitated a comparison between a variety of both energy and material biomass applications through the consideration of counterfactuals. The sensitivity analysis showed that, although variation in some parameters may influence the GHG outcome, the calculated GHG benefits or burdens of applications are robust.

Higher GHG benefits were found for bioenergy than for biomaterials, an observation also described by Hanssen et al. (2017) for woody biomass. An exception is the replacement of peat as a growth medium, which results in large $\mathrm{CH}_{4}$ emissions. Other authors have applied approaches similar to the comparison with counterfactuals in this study. These authors consider the indirect effects of products and often focus on fossil fuel replacement. For example, How et al. (2018) developed a simplified optimisation method for selecting processing technology and transport designs for residual biomass, including the replacement of fossil fuels in their environmental impact assessment. Similarly, Čuček et al. (2012) developed an approach to optimise supply chains considering various footprints and analyse the bioenergy applications of different biomass resources by considering the indirect effect of replacing fossil energy. These studies describe methodologies for the optimisation of supply chains in established biomass applications with the aim of maximising profits while minimising environmental impacts. The current study provides a novel comparison of currently feasible and practiced applications, highlighting the environmental impacts of using a particular set of biomass resources.

Two earlier publications reported the impacts of applications using residual biomass from landscape management in riverine areas. Recchia et al. (2010) analysed the environmental benefits of energy derived from riparian vegetation. These authors conducted a lifecycle analysis on woody biomass burnt in a $300 \mathrm{~kW}$ heat boiler reporting $\mathrm{CO}_{2}$-eq. emission reductions of between 78 and $83 \%$ in comparison with fossil energy production from natural gas. This type of energy generation is similar to the WH application in the current study, which would result in an equivalent $54 \%$ emission reduction. It should be noted that Recchia et al. (2010) did not include biogenic $\mathrm{CO}_{2}$ emissions in their analysis, while it accounted for $40 \%$ of emissions in this study $\left(\varepsilon_{B}\right.$, based on $\left.G W P_{b i o}\right)$. Excluding $\varepsilon_{B}$ from the current calculations results in a reduction of $74 \%$, which is close to the range described by Recchia et al. (2010), demonstrating the importance of considering biogenic $\mathrm{CO}_{2}$ emissions. Other differences are the assumed transport distance and harvesting machinery, and the use of a different $\mathrm{LCl}$ database. Differences in harvesting machinery parameters are due to different landscape characteristics of the study area (mainly woody biomass as opposed to mostly grassy biomass in the current study). Boscaro et al. (2018) analysed the GHG impacts of grass obtained from riverbank landscape management in biogas production. The authors calculated the GHG balance as the difference between the emissions of biogas production from grass and the fossil fuel emissions saved as a result of heat and electricity production with biogas. This is comparable to the GCHP application. The authors calculated GHG savings of between -67 and $-86 \mathrm{~kg} \mathrm{CO}_{2}$-eq. $/ \mathrm{t}_{\mathrm{wb}}$, based on different harvesting practices and logistical scenarios, both of which differed from the approach presented in this study. When using their reported transport distances of 5 and $10 \mathrm{~km}$ in the current calculations, emissions of $-74 \mathrm{~kg}$ and $-73 \mathrm{CO}_{2}$-eq. $/ \mathrm{t}_{\mathrm{wb}}$ result, which fall well within the range reported by Boscaro et al. (2018).

The contribution that residual biomass from vegetation management in river floodplains makes to climate change mitigation is an important ecosystem service (Koopman et al., 2018), but this residual biomass can also provide other services. Some of the applications discussed in this paper may have costs or benefits other than their GHG impact which may play a role in choosing a particular biomass application. Natural vegetation management with grazing animals, for example, 
may also provide cultural ecosystem services (Oteros-Rozas et al., 2014) and contribute to biodiversity recovery during river restoration (Straatsma et al., 2017). Removal of biomass for applications outside of the riparian area may result in carbon and nutrient losses. Carbon sources remain and decompose slowly under natural conditions but certain management practices result in their active removal and a rapid release of $\mathrm{CO}_{2}$. This has been described as a potentially problematic aspect in the harvest of stumps and logging residues (Lindholm et al., 2011), whole tree harvesting practices (Whittaker et al., 2011) and the removal of crop residues (Cherubini and Ulgiati, 2010). Leaving at least a part of the biomass on site may be advantageous for soil quality under certain conditions but is not always feasible due to flood safety regulations and disadvantageous from a GHG perspective. GCA demonstrated the highest GHG burden but can contribute to an increase in the organic matter content of agricultural soils. Soil quality is becoming increasingly important due to ongoing soil depletion in agriculture. Other factors may influence the choice of biomass applications and ideal combinations based on net GHG benefits alone may not be feasible in practice. For example, composting depends on inputs of woody biomass. The compost mixture would be too dense if only grassy biomass were composted, hindering aerobic processing. In practice, it may not be realistic to apply only residual woody biomass for energy production and only grassy biomass for composting to provide growth media.

Results of this study are based on calculations using carefully selected parameters. Limitations result from lack of data and simplifications which could be specified further in future research. For example, transport emissions could be specified considering optimisation under capacity constraints (How et al., 2016) and current workload of processing installations could be analysed to further define maximum current processing capacities. Future research could also extend to analysing additional impacts other than GHG emissions and compare new applications that are currently under development.

\title{
5 Conclusions
}

Removal and application of landscape biomass can contribute to climate change mitigation if GHG beneficial applications are chosen. This is true if landscape biomass can be removed without negative ecological consequences or has to be removed for other reasons, for example where riparian vegetation is removed to reduce flood risk. Producing heat or combined heat and power from woody biomass and growth media from compost of grassy biomass achieve the greatest GHG benefits, although the impact of growth media from compost is uncertain. Several other applications demonstrate GHG burdens and should be avoided from a climate change perspective.

In current river management practice the choice between different residual biomass applications depends on various factors including price, contribution to different ecosystem services, processing capacities of applications, and actors responsible for vegetation management (water management organisations, contractors or private land owners). It is essential that GHG benefits and burdens of different applications and their counterfactuals are considered to ensure that residual biomass makes a positive contribution to climate change mitigation.

\author{
Abbreviations \\ $\mathrm{cfl}$ - Counterfactual \\ CHP - Combined heat and power \\ d-Day \\ DM - Dry matter \\ GCA - Grassy biomass composting for agriculture \\ GCG - Grassy biomass composting for growth media \\ GCHP - Grassy biomass CHP
}


GFi - Grassy biomass fibres

GFo - Grassy biomass fodder

GGG - Grassy biomass green gas

GGS - Grassy biomass grazing sheep

GHG - Greenhouse gas

GLG - Grassy biomass large grazers

GLS - Grassy biomass left on site

$\mathrm{h}-$ Hour

ha - Hectare

kt - Kilotonne

MJ - Mega joule

$\mathrm{NL}$ - Netherlands

$\mathrm{t}$ - Tonne

TJ - Tera Joule

tkm - Tonne kilometre

$t_{w b}$ - Tonne wet biomass

WCHP - Woody biomass combined heat and power

WH - Woody biomass heat

WLS - Woody biomass left on site

\section{Acknowledgements}

We thank the stakeholders who provided valuable information for this study, specifically: Joyce Zuijdam, Yuri Wolf, Frank van Hedel, Marien Verwolf, Rick Kuggelein, Tim Brethouwer, Henk Vink, Edwin Hamoen, Jos Vrolijk, Eva Boon, Heleen Vreugdenhil and Maarten van Baren. This research forms part of the RiverCare research programme which is supported by the Dutch Technology Foundation STW, part of the Netherlands Organization for Scientific Research (NWO). The programme is partly funded by the Ministry of Economic Affairs under grant number P12-14 (Perspective Programme). We are thankful to Toine Smits for acquiring partial funding for the project (RiverCare-H). SVH and MAJH were supported by ERC grant 62002139 ERC-CoG SIZE 647224). The funding agencies were not involved in the design, execution and reporting of this study.

\section{Author contributions}

SFP, SVH and MAJH developed the study methodology. SFP collected information and input data for the selection and parameterisation of biomass applications and conducted the GHG calculations, assisted by SVH. MWS calculated the biomass transport distances. KRK, RSEWL and MWS contributed to the development of the method for the quantification of biomass production of floodplains. SVH and SFP conducted the sensitivity analysis. SFP, SVH and MAJH interpreted the results. SFP drafted the manuscript, and all authors revised the manuscript critically and approved the final content. RSEWL and MAJH acquired funding for this study. 


\section{References}

[dataset] Kadaster, 2017. Eigendomskaart - Eigenarenkaart. Supplied by RWS under the agreement of the funding programme, as described in the acknowledgement. Status October 2017. [WWW Document]. URL https://www.kadaster.nl/-/eigendomskaart-eigenarenkaart\#meer informatie

Baptist, M.J., Penning, W.E., Duel, H., Smits, A.J.M., Geerling, G.W., Van der Lee, G.E.M., Van Alphen, J.S.L., 2004. Assessment of the effects of cyclic floodplain rejuvenation on flood levels and biodiversity along the Rhine River. River Res. Appl. 20, 285-297. https://doi.org/10.1002/rra.778

Boscaro, D., Pezzuolo, A., Sartori, L., Marinello, F., Mattioli, A., Bolzonella, D., Grigolato, S., 2018. Evaluation of the energy and greenhouse gases impacts of grass harvested on riverbanks for feeding anaerobic digestion plants. J. Clean. Prod. 172, 4099-4109. https://doi.org/10.1016/j.jclepro.2017.02.060

Boschiero, M., Cherubini, F., Nati, C., Zerbe, S., 2016. Life cycle assessment of bioenergy production from orchards woody residues in Northern Italy. J. Clean. Prod. 112, 2569-2580. https://doi.org/10.1016/j.jclepro.2015.09.094

Bout, A.E., Pfau, S.F., Krabben, E. Van Der, Dankbaar, B., 2019. Residual Biomass from Dutch Riverine Areas - From Waste to Ecosystem Service. Sustainability 11, 509-523.

BVOR, 2016. Marktcijfers Producten uit organische reststromen in 2016.

Cherubini, F., Peters, G.P., Berntsen, T., Strømman, A.H., Hertwich, E., 2011. CO2 emissions from biomass combustion for bioenergy: atmospheric decay and contribution to global warming. GCB Bioenergy 3, 413-426. https://doi.org/10.1111/j.1757-1707.2011.01102.x

Cherubini, F., Ulgiati, S., 2010. Crop residues as raw materials for biorefinery systems - A LCA case study. Appl. Energy 87, 47-57. https://doi.org/10.1016/j.apenergy.2009.08.024

Creutzig, F., Ravindranath, N.H., Berndes, G., Bolwig, S., Bright, R., Cherubini, F., Chum, H., Corbera, E., Delucchi, M., Faaij, A., Fargione, J., Haberl, H., Heath, G., Lucon, O., Plevin, R., Popp, A., Robledo-Abad, C., Rose, S., Smith, P., Stromman, A., Suh, S., Masera, O., 2015. Bioenergy and climate change mitigation: An assessment. GCB Bioenergy 7, 916-944. https://doi.org/10.1111/gcbb.12205

Čuček, L., Varbanov, P.S., Klemeš, J.J., Kravanja, Z., 2012. Total footprints-based multi-criteria optimisation of regional biomass energy supply chains. Energy 44, 135-145. https://doi.org/10.1016/j.energy.2012.01.040

de Azevedo, A., Fornasier, F., da Silva Szarblewski, M., Schneider, R. de C. de S., Hoeltz, M., de Souza, D., 2017. Life cycle assessment of bioethanol production from cattle manure. J. Clean. Prod. 162, 1021-1030. https://doi.org/10.1016/j.jclepro.2017.06.141

De Ceuster, G., Voge, T., Chen, M., de Kievit, M., Laird, J., Koh, A., Sessa, C., Enei, R., Mascellaro, R., 2009. TREMOVE: Final Report. Model code v2.7b, 2009. Brussels.

Dornburg, V., van Vuuren, D., van de Ven, G., Langeveld, H., Meeusen, M., Banse, M., van Oorschot, M., Ros, J., Jan van den Born, G., Aiking, H., Londo, M., Mozaffarian, H., Verweij, P., Lysen, E., Faaij, A., 2010. Bioenergy revisited: Key factors in global potentials of bioenergy. Energy Environ. Sci. 3, 258. https://doi.org/10.1039/b922422j

Elshout, P.M.F., van Zelm, R., Balkovic, J., Obersteiner, M., Schmid, E., Skalsky, R., van der Velde, M., Huijbregts, M. a. J., 2015. Greenhouse-gas payback times for crop-based biofuels. Nat. Clim. Chang. 5, 604-610. https://doi.org/10.1038/nclimate2642

Gerssen-Gondelach, S.J., Saygin, D., Wicke, B., Patel, M.K., Faaij, A.P.C., 2014. Competing uses of biomass: Assessment and comparison of the performance of bio-based heat, power, fuels and materials. Renew. Sustain. Energy Rev. 40, 964-998.

https://doi.org/10.1016/j.rser.2014.07.197

Hanssen, S. V., Duden, A.S., Junginger, M., Dale, V.H., van der Hilst, F., 2017. Wood pellets, what else? Greenhouse gas parity times of European electricity from wood pellets produced in the 
south-eastern United States using different softwood feedstocks. GCB Bioenergy 9, 1406-1422. https://doi.org/10.1111/gcbb.12426

How, B., Lam, H.L., 2018. Sustainability evaluation for biomass supply chain synthesis: Novel principal component analysis (PCA) aided optimisation approach. J. Clean. Prod. 189, 941-961. https://doi.org/10.1016/j.jclepro.2018.03.104

How, B.S., Tan, K.Y., Lam, H.L., 2016. Transportation decision tool for optimisation of integrated biomass flow with vehicle capacity constraints. J. Clean. Prod. 136, 197-223. https://doi.org/10.1016/j.jclepro.2016.05.142

Kabat, P., van Vierssen, W., Veraart, J., Vellinga, P., Aerts, J., 2005. Climate proofing the Netherlands. Nature 438, 283-284. https://doi.org/10.1038/438283a

Kim, M.H., Song, H.B., 2014. Analysis of the global warming potential for wood waste recycling systems. J. Clean. Prod. 69, 199-207. https://doi.org/10.1016/j.jclepro.2014.01.039

Knörr, W., Schmied, M., Anthes, R., Seum, S., Kutzner, F., 2011. Ecological Transport Information Tool for Worldwide Transports (EcoTransIT): Methodology and data update. Berlin, Hannover, Heidelberg.

Koopman, K.R., Straatsma, M.W., Augustijn, D.C.M., Breure, A.M., Lenders, H.J.R., Stax, S.J., Leuven, R.S.E.W., 2018. Quantifying biomass production for assessing ecosystem services of riverine landscapes. Sci. Total Environ. 624, 1577-1585. https://doi.org/10.1016/j.scitotenv.2017.12.044

Lindholm, E.-L., Stendahl, J., Berg, S., Hansson, P.-A., 2011. Greenhouse gas balance of harvesting stumps and logging residues for energy in Sweden. Scand. J. For. Res. 26, 586-594. https://doi.org/10.1080/02827581.2011.615337

Middelkoop, H., Daamen, K., Gellens, D., Grabs, W., Kwadijk, J.C.J., Lang, H., Parmet, B.W.A.H., Schädler, B., Schulla, J., Wilke, K., 2001. Impact of Climate Change on Hydrological Regimes and Water Resources Management in the Rhine Basin. Clim. Change 49, 105-128. https://doi.org/10.1023/A:1010784727448

milieu centraal, 2018. Gemiddeld energieverbruik [WWW Document]. URL https://www.milieucentraal.nl/energie-besparen/snel-besparen/grip-op-jeenergierekening/gemiddeld-energieverbruik/ (accessed 5.1.18).

Oteros-Rozas, E., Martín-López, B., González, J.A., Plieninger, T., López, C.A., Montes, C., 2014. Sociocultural valuation of ecosystem services in a transhumance social-ecological network. Reg. Environ. Chang. 14, 1269-1289. https://doi.org/10.1007/s10113-013-0571-y

Pfau, S.F., 2015. Residual Biomass: A Silver Bullet to Ensure a Sustainable Bioeconomy?, in: The European Conference on Sustainability, Energy \& the Environment 2015: Official Conference Proceedings. pp. 295-312.

Recchia, L., Cini, E., Corsi, S., 2010. Multicriteria analysis to evaluate the energetic reuse of riparian vegetation. Appl. Energy 87, 310-319. https://doi.org/10.1016/j.apenergy.2009.08.034

Rijkswaterstaat, 2014. Toelichting op het onderdeel vegetatielegger.

RVO, 2018. BIO-Installaties [WWW Document]. URL https://ez.maps.arcgis.com/apps/webappviewer/index.html?id=c9e9bfcb647448ce97ad0fbb8f 05f7c7 (accessed 4.20.18).

Searchinger, T., Heimlich, R., Houghton, R.A., Dong, F., Elobeid, A., Fabiosa, J., Tokgoz, S., Hayes, D., Yu, T.-H., 2008. Use of U.S. Croplands for Biofuels Increases Greenhouse Gases Through Emissions from Land-Use Change. Science (80-. ). 319, 1238-1240. https://doi.org/10.1126/science.1151861

Smith, P., Bustamante, M., Ahammad, H., Clark, H., Dong, H., Elsiddig, E.A., Haberl, H., Harper, R., House, J., Jafari, M., Masera, O., Mbow, C., Ravindranath, N.H., Rice, C.W., Abad, C.R., Romanovskaya, A., Sperling, F., Tubiello, F., 2014. Agriculture, forestry and other land use (AFOLU), in: Edenhofer, O., Pichs-Madruga, R., Sokona, Y., Farahani, E., Kadner, S., Seyboth, K., Adler, A., Baum, I., Brunner, S., Eickemeier, P., Kriemann, B., Savolainen, J., Schlömer, S., Stechow, C. von, Zwickel, T., Minx, J.C. (Eds.), Climate Change 2014: Mitigation of Climate 
Change. Contribution of Working Group III to the Fifth Assessment Report of the Intergovernmental Panel on Climate Change. Cambridge University Press, Cambridge, United Kingdom and New York, NY, USA, pp. 811-922.

Stichting PRN, 2016. Resultaten monitoring inzameling en recycling niet-verpakkingstoepassingen van papier en karton, 2016.

Straatsma, M.W., Bloecker, A.M., Lenders, H.J.R., Leuven, R.S.E.W., Kleinhans, M.G., 2017. Biodiversity recovery following delta-wide measures for flood risk reduction. Sci. Adv. 3, 1-10. https://doi.org/10.1126/sciadv.1602762

Straatsma, M.W., Kleinhans, M.G., 2018. Flood hazard reduction from automatically applied landscaping measures in RiverScape, a Python package coupled to a two-dimensional flow model. Environ. Model. Softw. 101, 102-116. https://doi.org/10.1016/j.envsoft.2017.12.010 Van der Molen, D., Geilen, N., Backx, J., Jansen, B., Wolfert, H., 2003. Water Ecotope Classification for integrated water management in the Netherlands. Eur. Water Manag. Online 1-14.

Wernet, G., Bauer, C., Steubing, B., Reinhard, J., Moreno-Ruiz, E., Weidema, B., 2016. The ecoinvent database version 3 (part I): overview and methodology. Int. J. Life Cycle Assess. 21, 1218-1230.

Whittaker, C., Mortimer, N., Murphy, R., Matthews, R., 2011. Energy and greenhouse gas balance of the use of forest residues for bioenergy production in the UK. Biomass and Bioenergy 35, 4581-4594. https://doi.org/10.1016/j.biombioe.2011.07.001 